\title{
Change of polyphenol oxidase activity during oolong tea process
}

\author{
Nguyen Ngoc Tram ${ }^{1,}$, Phan Phuoc Hien², Huynh Ngoc Oanh ${ }^{1}$ \\ ${ }^{1}$ Faculty of Chemistry, Department of Biochemistry, University of Technology HCMC, Vietnam \\ ${ }^{2}$ Faculty of Food and Life Sciences, University of Hung Vuong, HCMC, Vietnam
}

Email address:

nguyenngoctram14@gmail.com (N. N. Tram), ngocoanh_huynh@yahoo.com (H. N. Oanh), pphien@gmail.com (P. P. Hien)

\section{To cite this article:}

Nguyen Ngoc Tram, Phan Phuoc Hien, Huynh Ngoc Oanh. Change of Polyphenol Oxidase Activity during Oolong Tea Process. Journal of Food and Nutrition Sciences. Special Issue: Food Processing and Food Quality. Vol. 3, No. 1-2, 2015, pp. 88-93.

doi: $10.11648 /$ j.jfns.s.2015030102.27

\begin{abstract}
It was believed that catechins produced theaflavins (TF) and low molecular weight, chromatographically resolved thearubigins (TR) in the presence of polyphenol oxidase (PPO). So, the changes of oolong tea PPO activity, tannin, TF, TR contents were considered. Green tea leaves were going through the stages: fresh tea $\rightarrow$ withering $\rightarrow$ fermentation $\rightarrow$ dried inactivated enzyme $\rightarrow$ final products. Tea samples in the stages were conducted. Enzyme PPO from tea samples was extracted by $0.1 \mathrm{M}$ phosphate buffer ( $\mathrm{pH} 7.5)$, addition of $1 \%$ PEG (v/v). PPO activity was determined by a spectrophotometer at $420 \mathrm{~nm}$ with pyrocatechol as standard. The results showed that the PPO activity increased from fresh tea leaves (100\%) to the withering stage $(111.89 \%)$, decreased steadily in the rolled 1 (96.83\%). Then, the PPO activity fluctuated continuously, peaked at the incubated 2 and 3 and fell sharply after that. The enzyme activity in the final product was $7.95 \%$ compared with the fresh one. PPO activity had a positive influence on the TF/TR ratio and catechins depletion.
\end{abstract}

Keywords: Polyphenol, Polyphenol Oxidase, PPO, Microwave-Treated, Oolong tea, Tannin, Theaflavins, Thearubigins

\section{Introduction}

Tea, Camellia sinensis L., is a rich source of compounds with bioactive properties, such as antioxidant and antimicrobial activities [1]. According to Muigai Ngure Francis et al (2009), the quality of black tea is dependent on the total theaflavin and theaflavin digallate levels. Theaflavin determined compression (density), brightness, color, cavitation and thearubigin related to the intensity and color of black tea [2-4]. Theaflavin is the product of oxidation compounds under catalytic catechin polyphenol oxidase enzyme (PPO). During the catalytic reaction, $\mathrm{H}_{2} \mathrm{O}_{2}$ is generated. Now, peroxidase (POD) will participate in the metabolic reactions theaflavin, thearubigin [5].

Polyphenol oxidase (PPO) plays a key role in the oxidation of flavanols to black tea components such as theaflavins (TF) and thearubigins (TR). The polyphenol oxidase (PPO) activity has been reported to be higher in internodes compared with leaves; and, among the leaves, tender leaves have higher enzyme activity than mature leaves $[6,7]$. The levels of polyphenol oxidase (PPO) activity and the polyphenolic content changed significantly with plucking season and shoot maturity. No significant difference was observed between the total polyphenolic content of the cold storage withered and traditionally withered samples [8].

Microwave cooking is also increasingly used as a timesaving technology but it induces severe changes in the lipids, such as hydrolysis and oxidative reactions that lead to quality and nutritional losses. According to Ricardo Malheiro et al, (2012) white and green tea aqueous extracts were used to increase olive oil stability under microwave cooking because of their wealthy antioxidants [1]. It indicated that the tea antioxidants were endurable under microwave heating. Moreover, the effect of enzyme inactivation by microwave heating time was determined on the quality of tea. And the preservation qualities of green tea harvested were greatly enhanced by microwave heating [9].

In this study, the changes of PPO activity in oolong tea manufacturing and the relationship of PPO activity and phenolic compounds was conducted. The tea samples were divided into 2 parts: an inactivated enzyme group - treated by microwave (group 1) and an active enzyme group (group 2 ). The inactivated enzyme one was used to analysis the total polyphenol, tannin contents and PPO activity. For the other one, TF and TR content was analysis. 


\section{Materials and Method}

\subsection{Materials}

The green tea - raw material for Oolong tea production, which was made from the leaves of Camellia sinensis L. in April, 2014, was kindly provided by Cau Tre Tea Factory (Lam Dong province, Vietnam).

\subsection{Moisture}

Tea moisture was measured using a vacuum oven based on an international standard method [10].

\subsection{Determination of Total Polyphenols of Tea Samples}

In due to protect tea polyphenol compounds, $5 \mathrm{~g}$ fresh tea shoots were inactivated enzyme by using microwave heating in the high-pressure reactor $1100 \mathrm{~W}$ (Microwave Sharp 33L R-399VN (S) 1100W) for 20 seconds before using.

For determination of total polyphenols $1 \mathrm{~g}$ of tea powder (group 1) was added to $30 \mathrm{ml}$ in a $100 \mathrm{ml}$ flash and boiled in $100^{\circ} \mathrm{C}$ for 30 minutes. Then, the solution was filtered, cooled to room temperature. It was diluted to $100 \mathrm{ml}$ with distilled water after that.

The tartrate solution was prepared by dissolving $1 \mathrm{~g}$ of $\mathrm{FeSO}_{4}$ and $5 \mathrm{~g}$ of $\mathrm{KNaC}_{4} \mathrm{H}_{4} \mathrm{O}_{6}$ in distilled water, and the volume is made up to $1000 \mathrm{ml}$. The phosphate buffer solution consists of $85 \%(\mathrm{v} / \mathrm{v})$ of $\mathrm{Na}_{2} \mathrm{HPO}_{4}$ solution and $15 \%$ (v/v) of $\mathrm{KH}_{2} \mathrm{PO}_{4}$ solution.

In according to Yao et al (2006), one milliliter of tea solution, $4 \mathrm{ml}$ of distilled water and $5 \mathrm{ml}$ of tartrate solution were taken in a volumetric flask and then diluted to $25 \mathrm{ml}$ with phosphate buffer solution. The mixture absorbance was measured at $540 \mathrm{~nm}$ using spectrophotometer. The tea samples were analyzed in duplicate for total polyphenols [10, $11]$.

$$
\text { Torlpolyphon }(\%)=\frac{3.914 \times E \times V_{1} \times 100}{1000 \times V_{2} \times w}
$$

where

E: absorbance reading

$\mathrm{V}_{\mathrm{o}}$ : total volume of the solution $(250 \mathrm{ml})$

$\mathrm{V}_{1}$ : the volume used for the measurement $(1 \mathrm{ml})$

W: dry weight of the tea sample

The polyphenol content was $3.914\left(\mathrm{mg} \cdot \mathrm{ml}^{-1}\right)$ when the absorbance value was 1.0 [12]

\subsection{Determination of Tannic Acid Content by HPLC method}

$1 \mathrm{ml}$ the above solution after using to determine the total polyphenol was diluted to $10 \mathrm{ml}$ with methanol. After that, the solution was filtered through a $0.45 \mu \mathrm{m}$ membrane. Then, the solution was analyzed by HPLC method, tannic acid as a standard.

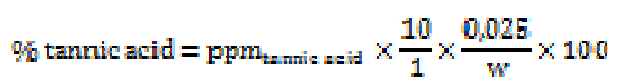

Analysis conditions: The mobile phase (Metanol: water (30: $70 \mathrm{v} / \mathrm{v})$ ); mobile phase speed: $0.75 \mathrm{ml} / \mathrm{min}$; C18 column, Detector Diod Array; injection volume: $5 \mu \mathrm{l}$; 280nm [13-15].

\subsection{Determination of PPO Activity}

$10 \mathrm{~g}$ tea powder (group 2) was added into a $100 \mathrm{ml}$ beaker (coated foil), added $50 \mathrm{ml}$ phosphate buffer solution ( $\mathrm{pH} 7.5$ supplemented with polyethylene glycol $1 \%(\mathrm{w} / \mathrm{v}))$. The mixture was stirred for $30 \mathrm{~min}$ at $4^{\circ} \mathrm{C}$. After being filtered, the supernatant was centrifuged at 3000 rounds within 10 minutes.

$0.05 \mathrm{ml}$ the supernatant, $2.85 \mathrm{ml}$ phosphate buffer solution $(\mathrm{pH} 8)$ and $0.1 \mathrm{ml}$ pyrocatechol solution $0.05 \mathrm{M}$ was added into a cuvette and the absorbance value at $420 \mathrm{~nm}$ was recorded. One unit of PPO activity was defined as the amount of enzyme needed to metabolize pyrocatechol into a $\mu$ mol benzoquinone per minute.

$$
\text { FPOactivity }==\frac{A \times 3 \times 10^{\circ}}{0.05 \times 2 \times 2}
$$

Where,

$\varepsilon_{420 \text { benzoquinone }}=24300 \mathrm{M}^{-1} \mathrm{~cm}^{-1}[16]$.

A: the absorbance value at $420 \mathrm{~nm}$

$\mathrm{t}$ : the reaction time $(\mathrm{min})$

\subsection{Estimation of Theaflavins (TF), Thearubigins (TR) by Spectrophotometry}

TF and TR are the products of catechin metabolism under the influence of polyphenol oxidase. To evaluate the performance of the PPO, the tea of group 2 were investigated.

$2.5 \mathrm{~g}$ of tea powder (group 2) was added to $25 \mathrm{ml}$ in a 100 $\mathrm{ml}$ flash and boiled in $100^{\circ} \mathrm{C}$ for 30 minutes. Then, the solution was filtered, cooled to room temperature and diluted to $50 \mathrm{ml}$ with the distilled water. The contents of TF, TR were calculated from the absorbance values based on the description of tea researchers Takeo and Oosawa (1976) [6, 17]

\subsection{Statistical Analysis}

The analysis of variance of the quality parameters and chemical composition data was analyzed by the Statgraphics Centurion XV software. The significance of differences at a $5 \%$ level between averages was determined by one-way ANOVA using T-test.

\section{Results and Discussion}

\subsection{The Metamorphosis of Tea Leaves in Oolong Tea Manufacturing}

The Oolong tea manufacturing was divided into stages: fresh $\rightarrow$ withering $\rightarrow$ fermented $\rightarrow$ dried $\rightarrow$ final product. In particular, the fermented process was divided into smaller stages: incubated and rolled many times. The temperature of fermentation was maintained between $15-18^{\circ} \mathrm{C}$. This was the optimal enzyme temperature. John B. Cloughley (1980) 
had investigated the impact of temperature on enzyme activity during fermentation of black tea industry [18]. The impact of temperature on the rate of inactivation was also much greater on polyphenoloxidase (PPO). Their results showed that the activity of peroxidase (POD) changed significantly (Figure 1), the PPO also decreased with increasing temperature.

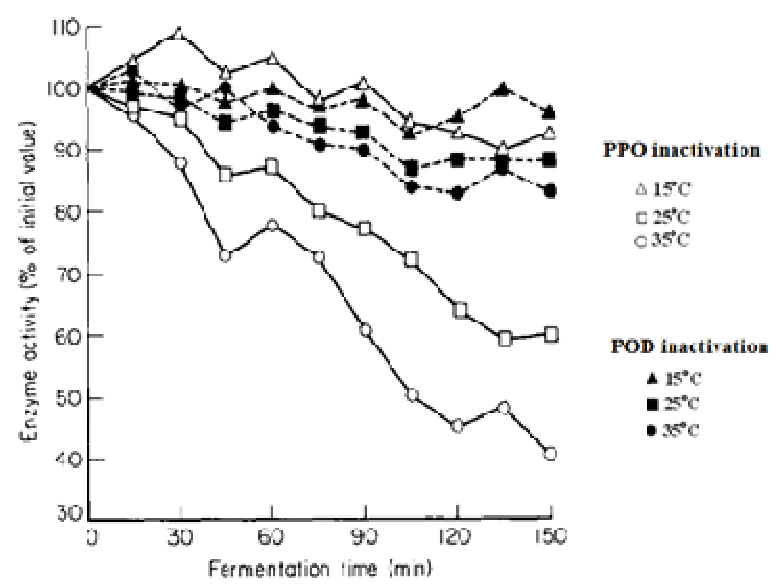

Figure 1. Effect of temperature on enzyme inactivation during fermentation of Indian hybrid seedling

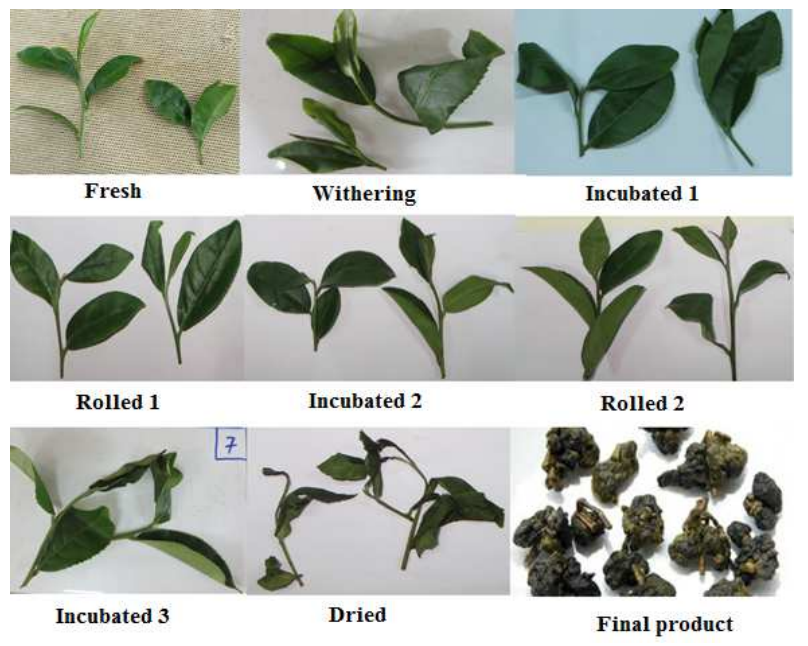

Figure 2. The metamorphosis of tea leaves in Oolong tea manufacturing

The shapes of tea leaves from the fresh to the incubated 3 stage changed negligibly (Figure 2). In particular, the structures of tea leaves from the fresh stage to the incubation period 1 were withered as a result of respiration and some of the physiological and biochemical changes. According to Tombs and Mashingaidze (1997), the total catechin content decreased during withering. Epigallocatechin (EGC), gallocatechin (GC), epigallocatechin gallate (EGCG) and epicatechin gallate (ECG) reduced while the epicatechin (EC) increased [19]. Theaflavins (TF) and thearubigins (TR) was the product of the decomposition of catechins compounds under the catalysis of PPO and POD. PPO activity decreased during withering as a result of the evaporation. In India, the withering method seemed to be a little influence of PPO or POD. PPO activity was restored after the leaves are withering provide additional moisture. The activity of the enzyme decreases as the temperature increases [18].

The tea samples from the rolled 1 to incubated 3 period, the young leaves were shanked, toughened, dried and dark green slowly. At the dried period, the shape was changed significantly. The moisture content was down more than $30 \%$ to make the edge become crunchy. Then, the tea leaves were cooled at room temperature to help their structure toughen again. Leaf morphology after shaping and moisture drying to less than 5\% was observed in the final product period (Figure 2).

\subsection{Changes of Polyphenol Oxidase Activity in Oolong Tea Manufacturing}

Generally, the PPO activity decreased in Oolong tea processing. In fresh tea, its activity was high (100\%), increased to $111.89 \%$ in the withering, decreased steadily in the rolled $1(96.83 \%)$. Then, the PPO activity fluctuated continuously, peaked at the incubated 2 and 3 and fell sharply after that. The enzyme activity in the final product was 7.95\% compared with the fresh one. The results were similar to the study of Pradip K. Mahanta et al (1993). But the object of his research was the black tea, but basically, fermented teas are experiencing the fresh, withering, rolled and fermented stage [20] (Figure 6).

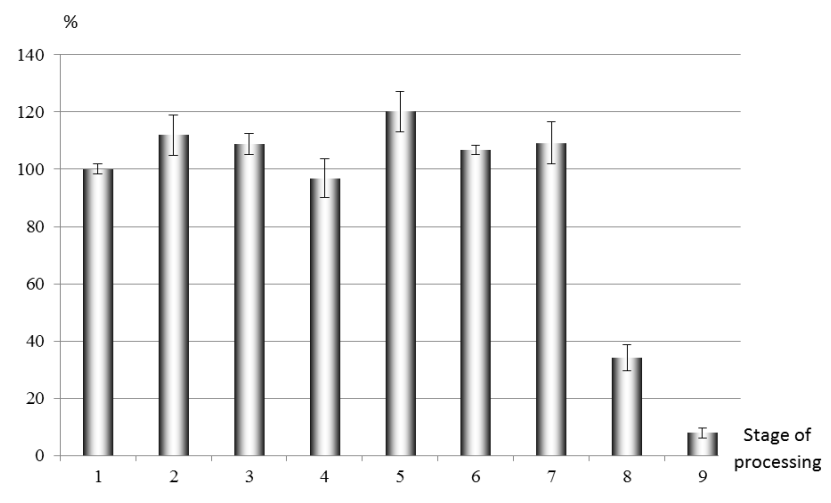

Figure 3. Changes of polyphenol oxidase activity in Oolong tea manufacturing.



Figure 4. Specific enzyme activities of PPO and PO at different stages of manufacture [20]

When, 
$1-$ Fresh

\section{$4-$ Rolled 1}

2 -Withering 5 - Incubated 2

3 - Incubated $1 \quad 6$ - Rolled 2
7 - Incubated 3

$8-$ Dried

9 - Final product

\subsection{Changes of Phenolic Compounds in Oolong Tea Manufacturing}



Figure 5. Changes of total polyphenol and tannic acid in Oolong tea manufacturing.

The fluctuations in total polyphenol and tannic acid content were similar and have the same downward trend PPO enzyme activity (In Figure 3). However, both tannic acid and total polyphenol increased slightly in the withering stage and decreased slowly after that. In the final stage, the total polyphenol and tannin content were $7.11 \%$ and $0.6 \%$, respectively.

Theaflavins (TF), thearubigins (TR) and bis flavanols

were three components influenced on the color of the tea liquors. Overall, the TF/TR ratio and total color had a closer relationship. According to Yao et al (2006), the average levels of TF and TR in black tea samples were $0.75 \%$ and $7.61 \%$, respectively; in green tea were $0.18 \%$ and $7.42 \%$, respectively [10]. On the other hand, the results of the TF, TR contents in group 1 were similar to their content in green tea, but in group 2 looked like the black tea. According to Ferruzzi et al (2010), the fermented tea was unlike green tea, in the production process, under the action of the enzyme polyphenol oxidase, the catechin monomer was oxidized and create a complex mixture of polyphenols include theaflavin, theasinensin, oxidation and polymer complex has not been described, such as thearubigin [20-23].



Figure 6. Changes of TF/TR content and total color in Oolong tea manufacturing

Table 1. The relationship of TF, TR and PPO activity

\begin{tabular}{|c|c|c|c|c|c|c|c|}
\hline \multirow{2}{*}{ Stage } & \multicolumn{3}{|c|}{ Group 2 (natural/untreated enzyme) } & \multicolumn{2}{|c|}{ Group 1 (assisted by microwave treatment) } & \multirow{2}{*}{$\Delta \mathrm{TF}(\%)$} & \multirow{2}{*}{$\Delta \mathrm{TR}(\%)$} \\
\hline & PPO activity (UI) & TR (\%) & TF (\%) & TF (\%) & TR (\%) & & \\
\hline Fresh & $100.00 \pm 2.16^{\mathrm{a}}$ & $7.91 \pm 0.14^{\mathrm{a}}$ & $0.47 \pm 0,025^{a b}$ & $0.07 \pm 0.009^{\mathrm{a}}$ & $7.34 \pm 0.55^{a b}$ & 0.010 & 0.060 \\
\hline Withering & $80.03 \pm 1.10^{\mathrm{bc}}$ & $6.92 \pm 0.08^{b}$ & $0.48 \pm 0,025^{\mathrm{a}}$ & $0.05 \pm 0.009^{b}$ & $8.15 \pm 0.315^{\mathrm{cd}}$ & 0.007 & 0.069 \\
\hline Incubated 1 & $82.94 \pm 0.54^{b}$ & $6.03 \pm 0.39^{\mathrm{cd}}$ & $0.37 \pm 0,025^{\mathrm{cd}}$ & $0.05 \pm 0.007^{b}$ & $7.86 \pm 0.343^{\text {acd }}$ & 0.006 & 0.061 \\
\hline Rolled 1 & $64.45 \pm 0.51^{\mathrm{d}}$ & $6.30 \pm 0.69^{b c}$ & $0.40 \pm 0,015^{\text {ce }}$ & $0.11 \pm 0.009^{\mathrm{c}}$ & $7.79 \pm 0.673^{\mathrm{ac}}$ & 0.014 & 0.063 \\
\hline Incubated 2 & $60.54 \pm 1.57^{\mathrm{e}}$ & $5.99 \pm 0.48^{\mathrm{cd}}$ & $0.33 \pm 0,025^{\mathrm{d}}$ & $0.09 \pm 0.007^{\mathrm{de}}$ & $7.31 \pm 0.273^{\mathrm{ab}}$ & 0.012 & 0.054 \\
\hline Rolled 2 & $74.46 \pm 6.45^{\mathrm{cd}}$ & $5.48 \pm 0.16^{\mathrm{d}}$ & $0.44 \pm 0,025^{\text {be }}$ & $0.10 \pm 0.007^{\mathrm{ce}}$ & $7.50 \pm 0.208^{\mathrm{ac}}$ & 0.013 & 0.080 \\
\hline Dried & $26.10 \pm 5.98^{\mathrm{f}}$ & $8.53 \pm 0.24^{\mathrm{a}}$ & $0.08 \pm 0,025^{f}$ & $0.11 \pm 0.007^{c}$ & $6.65 \pm 0.258^{b}$ & 0.016 & 0.010 \\
\hline Final product & $5.42 \pm 1.69^{g}$ & $12.33 \pm 0.44^{\mathrm{e}}$ & $0.16 \pm 0,025^{\mathrm{g}}$ & $0.16 \pm 0.006^{f}$ & $12.32 \pm 0.343^{\mathrm{e}}$ & 0.013 & 0.013 \\
\hline
\end{tabular}

The data represented by the table were the averages of triplicates \pm standard deviations. Letters above the bar indicate significant different values. Different lowercases letters on the histongraphs with the same pattern indicate the significant differences $(\mathrm{P}<0.05)$

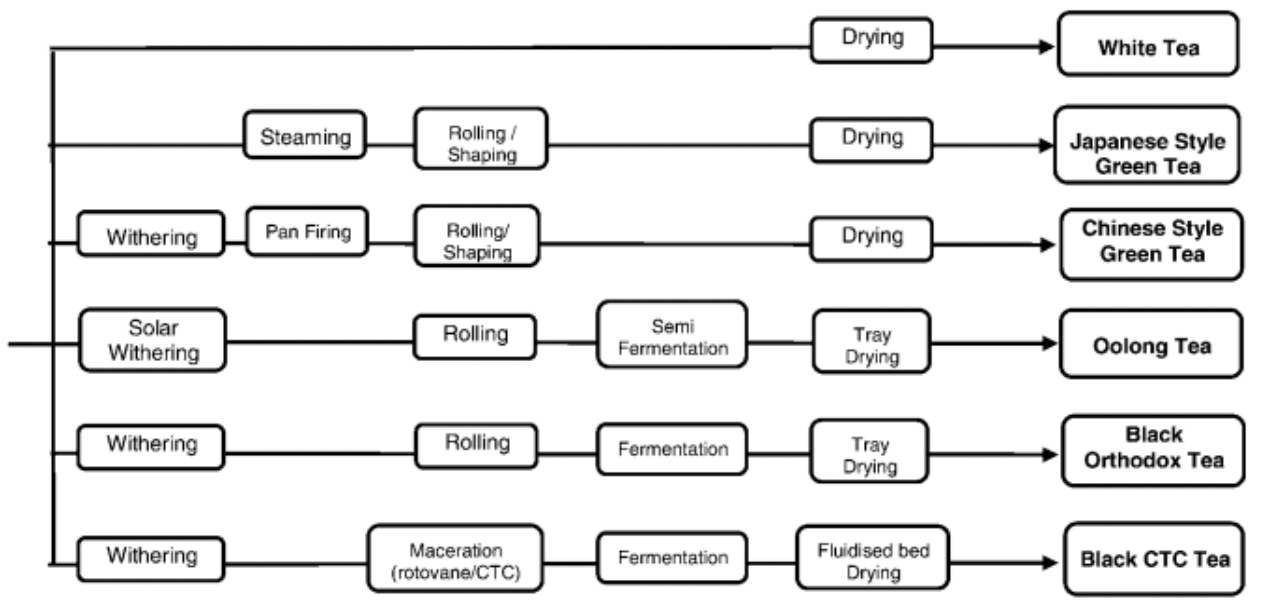

Figure 7. Tea manufacture - major steps and corresponding types of tea 


\subsection{The Relationship of PPO Activity and Total Polyphenol, Tannic Acid Content}

Under the effect of microwaves, the polyphenols were protected from the effects of the intracellular enzyme. Comparison of total polyphenols, tannic acid contents and the activity of PPO in Figures 3 and 5, the total polyphenol and tannin content peaked in withering stage. It was similar to PPO activity.

\subsection{The Relationship of PPO Activity and $\triangle T F, \triangle T R$ Content}

In table $1, \mathrm{TF}$, TR content in group 1 and 2 was analyzed. It was showed that the fluctuation of TF/TR ratio was similar to the total polyphenol, tannic acid contents. It peaked in the withering, rolled 1 , rolled 2 and incubated 3 periods. It was the same to the relationship between PPO activity and total polyphenol content, total tannin. In group 2 , the TF content was higher than the group 1 . However, the TR in group 1 was higher than the group 2. It means that there was a transformation between TF and TR.

\section{Conclusion}

The present study outlines the significance of enzymes to Oolong tea quality by demonstrating the changes they undergo during various cultural and manufacturing operations. The PPO activity was strong in the incubated stages. Under the effect of microwaves, the polyphenols were protected from the effects of the intracellular enzyme. Therefore, the potential applications in microwave processing technologies for the production of tea were possible.

\section{Acknowledgements}

We gratefully acknowledge the financial support from Cau Tre Export Goods Processing Joint Stock Company. We also extend special thanks to Cau Tre Tea Factory for kindly providing tea material.

\section{References}

[1] Ricardo Malheiro; Susana Casal; Hugo Lamas; Albino Bento; José Alberto Pereira, "Can tea extracts protect extra virgin olive oil from oxidation during microwave heating?," Food Research International, vol. 48, pp. 148-154, 2012.

[2] A. K. Biswas, Biswas, A. K., \& Sarkar, A., "Biological and chemical factors affecting the valuations of North-East Indian plain teas," Journal of the Science of Food and Agriculture, vol. 24, pp. 1457-1477, 1973.

[3] M. Obanda, Owuor, P. O., \& Mang'oka, R., " Changes in the chemical and sensory quality parameters of black tea due to variations of fermentation time and temperature," Food Chemistry, vol. 75, pp. 395-404, 2001.
[4] S. N. Stephen Thanaraj, "Influence of Polyphenol Oxidase Activity and Polyphenol Content of Tea Shoot on Quality of Black Tea," J. Sci Food Agric vol. 51, pp. 57-69, 1990.

[5] Biswas A. K.; Biswas A. K.; Sarka A, "Biological and chemical factors affecting the valuations of North-East Indian plain teas," Journal of the Science of Food and Agriculture, vol. 24, pp. 1457-1477, 1973.

[6] Thanaraj S.N.S.; Seshadri R., "Influence of polyphenol oxidase activity and polyphenol content of tea shoot on quality of black tea," Journal of the Science of Food and Agriculture, vol. 51, pp. 57-69, 1990.

[7] Buzun G.A.; Dzhemukhadze K.M. And Mileshko L.F., "ODiphenol oxidase of tea and quality of the raw material," Subtrop Ku'lt, vol. 1, pp. 35-38, 1984.

[8] Hülya Ölmez and Aysun Yilmaz, "Changes in chemical constituents and polyphenol oxidase activity of tea leaves with shoot maturity and cold storage," Journal of Food Processing and Preservation, vol. 34, pp. 653-665, 2010.

[9] Yuanyuan Huang; Jianchun Sheng; Fangmei Yang; Qiu Hui $\mathrm{Hu}$, "Effect of enzyme inactivation by microwave and oven heating on preservation quality of green tea," Journal of Food Engineering, vol. 78, pp. 687-692, 2007.

[10] L.H. Yao; Y.M. Jiang; N. Caffin; B.D Arcy; N. Datta; X. Liu; R. Singanusong; Y. Xu, "Phenolic compounds in tea from Australian supermarkets," Food Chemistry, vol. 96, pp. 614620, 2006.

[11] Liang Y; Lu J; Zhang L; Wu S; Wu Y, "Estimation of black tea quality by analysis of chemical composition and colour difference of tea infusions," Food Chemistry, vol. 80, pp. 283290, 2003.

[12] Nihal Turkmen; Ferda Sari; Y. Sedat Velioglu, "Effects of extraction solvents on concentration and antioxidant activity of black and black mate tea polyphenols determined by ferrous tartrate and Folin-Ciocalteu methods," Food Chemistry, vol. 99, pp. 835-841, 2006.

[13] D. Cozzolino; M.J. Kwiatkowski; M. Parker; W.U. Cynkar; R.G. Dambergs; M. Gishen; M.J. Herderich, "Prediction of phenolic compounds in red wine fermentations by visible and near infrared spectroscopy," Analytica Chimica Acta, vol. 513, pp. 73-80, 2004.

[14] C.J. Sarneckis; R.G. Dambergs; P. Jones; M. Mercurio; M.J. Herderich and P.A. Smith, "Quantification of condensed tannins by precipitation with methyl cellulose: development and validation of an optimised tool for grape and wine analysis," Australian Journal of Grape and Wine Research, vol. 12, pp. 39-49, 2006.

[15] Giang Trung Khoa; Nguyễn Thanh Hải; Ngô Xuân Mạnh; Nguyễn Thị Bích Thủy; Phạm Đức and Nghĩa; Nguyễn Thị Oanh; Phan Thu Hương; P. Duez, "Ảnh hưởng của nguồn nguyên liệu đến thành phần hóa học cơ bản của giống chè trung du (camellia sinensis var. Sinensis)," Tap chi Khoa hoc và Phát triể, vol. 11, pp. 373-379, 2013.

[16] E. A. Braude, "Studies in light absorption. Part I. pBenzoquinones," J. Chem. Soc., vol. 45, pp. 490-497, 1945.

[17] Takeo T; Oosawa K, "Photometric analysis and statistical evaluation of black tea infusion," Bull National Res Inst Tea (Japan), vol. 12, pp. 125-181, 1976. 
[18] John B. Cloughley, "The Effect of Temperature on Enzyme Activity During the Fermentation Phase of Black Tea Manufacture " Journal of the Science of Food and Agriculture, vol. 31, pp. 920-923, 1980.

[19] K I Tombs \& A Mashingaidze, "A Review Influence Of Withering, Including Leaf Handling, On The Manufacturing And Quality Of Black Teas," Food Chemistry, vol. 60, pp. 573-580, 1997.

[20] Pradip K. Mahanta; Santanu K. Boruah; Hemanta K. Boruah; Jatindra N. Kalita, "Changes of Polyphenol Oxidase and Peroxidase Activities and Pigment Composition of Some Manufactured Black Teas (Camellia sinensis L.)," Journal of Agricultural and Food Chemistry, vol. 41, pp. 272-276, 1993.
[21] Mario G. Ferruzzi, "The influence of beverage composition on delivery of phenolic compounds from coffee and tea," Physiology \& Behavior, vol. 100, pp. 33-41, 2010.

[22] Lin L; Lei F; Sun Dw; Dong Y; Yang B; Zhao M, "Thermal inactivation kinetics of Rabdosia serra (Maxim.) Hara leaf peroxidase and polyphenol oxidase and comparative evaluation of drying methods on leaf phenolic profile and bioactivities," Food Chemistry, vol. 134, pp. 2021-2029, 2012.

[23] Shengmin Sang; Chung S. Yang; Chi-Tangho, "Peroxidasemediated oxidation of catechins," Phytochemistry, vol. 3, pp. 229-241, 2004. 